\title{
Descriptions of therapeutic arthrocenthesis and of synovial fluid in a Nahuatl text from prehispanic Mexico
}

\author{
DONATO ALARCON-SEGOVIA
}

From the Department of Immunology and Rheumatology, Instituto Nacional de la Nutrición, Mexico 22 DF, Mexico

SUMMARY Paracelsus is considered to have been the first to record the viscid quality of the synovial fluid. However, his contemporary Bernardino de Sahagún, a Franciscan friar who came to Mexico shortly after the Spanish conquest, obtained from elderly Aztec Indians who spoke only Nahuatl the descriptions of therapeutic arthrocentesis and of the viscid nature of the synovial fluid. They compared the fluid from the knee joint to the viscid fluid from the leaves of the nopal cactus (Opuntia sp.). We here record their description and confirm the accuracy of their comparison.

It is generally considered that the Swiss Renaissance physician Phillipus Aureolus Theophrastus Bombastus von Hohenheim, better known as Paracelsus (1493-1541), was the first to note the presence of a viscid fluid within the joint cavity. ${ }^{1,2}$ Paracelsus was a brilliant man who collected as many admirers as critics during his lifetime. He was a wanderer who alienated many of his colleagues and who, despite being a great medical practitioner for his time, never decided whether his main interest was natural science, magic cabalistic knowledge, or alchemy. ${ }^{3,4}$

Very different from Paracelsus was his contemporary Bernardino de Sahagún (1499-1590) (Fig. 1), a Franciscan friar who arrived in Mexico in 1529 only 8 years after the conquest of Tenochtitlan, the Aztecs' capital, by Hernán Cortés. He immediately dedicated himself and continued to do so until his death, to the acquisition and classification of information on many aspects of the Indian cultures of central Mexico (the Nahuatl cultures). The method he used was highly advanced for his time. ${ }^{5} \mathrm{He}$ developed questionnaires covering all matters that he wanted to investigate. These questionnaires included questions on rites, priests and gods, festivities and customs, family relationships, legends, education, child raising, medicine, nutrition, botany, animals, metals, ethnic origin, literature, and even the Indian version of the history of the Spanish conquest. $^{5}$

Accepted for publication 8 June 1979

Correspondence to Professor Alarcon-Segovia.
His method was first applied at Tetepulco, a place close to present-day Mexico City, where he had the elders of the region answer the questionnaires by reference to their own paintings and manuscripts. The version of the old Indians was transcribed by various young Indians who had learned to write the Nahuatl language in alphabetic characters. The material obtained was extensive and valuable. The first draft a document known as the First

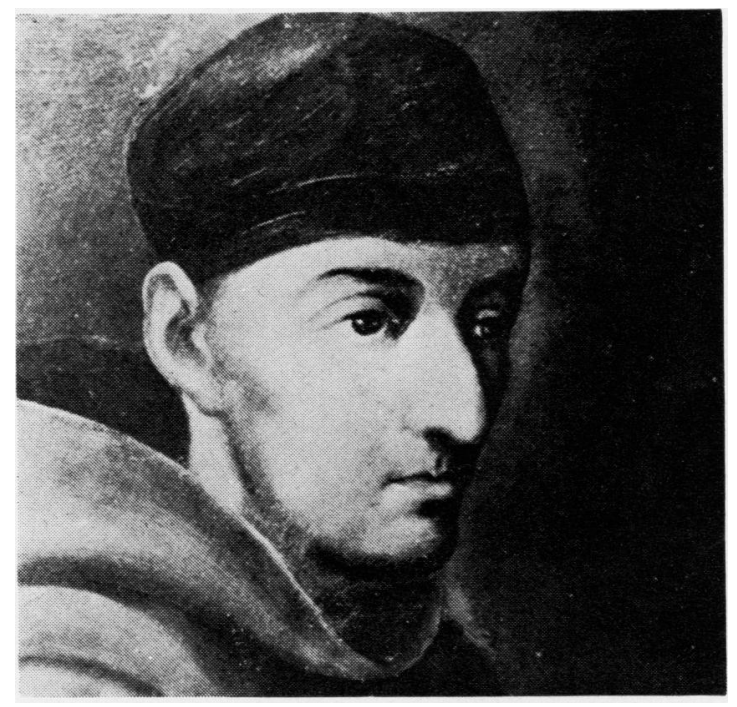

Fig. 1 Friar Bernardino de Sahagún (1499-1590) 
Memorials, enabled Sahagún to develop other more complete questionnaires, which he applied in MexicoTlatelolco. They resulted in a new draft, and it was accidentally divided in two codices which, on the requisition of the Spanish King Phillip II, are now both in Madrid. The material was personally revised by Sahagún as well as by experts whom he appointed to revise each subject.

The final collection, which amounted to a selection, has 2 versions, one the Florentian codex which includes Nahuatl and Spanish versions side by side, and the other the Spanish version proper, which is known as 'General History of the Things of the New Spain', the latest edition of which was published in 4 volumes in $19566^{6}$ Medical topics in the last 2 versions were reviewed by 8 Nahuatl physicians who corrected the manuscript. However, they can also be found both in the Tetepulco and MexicoTlatelolco's drafts as well as in the Florentian codex. The medical aspects of this material have recently been studied by López-Austin, ${ }^{7}$ who divided it, after Sahagún, into a part pertaining to human diseases, a part pertaining to medicines, and a part pertaining to the anatomy of the human body. López-Austin's study ${ }^{7}$ goes back to the First Memorials, which he translated from Nahuatl. There are 2 texts on 'Diseases of the Body'. Both were obtained in Tetepulco and appear to have come from different informants or at least from the answers to different questionnaires. ${ }^{7} \mathrm{~A}$ third text that appears in the Florentian codex was revised and completed by the 8 'referee' Indian physicians. ${ }^{7}$ The first of these 3 texts, which consist of a list of diseases with their corresponding treatment, reads as follows:

\section{FORMATION OF VISCID FLUID IN}

THE KNEES

It is cured by bleeding with a pointed thorn. Something comes out that is akin to the viscid fluid of the nopal.

Several notions are present in this Nahuatl text. Although it was compiled in Sahagún's time, the method by which it was obtained strongly suggests that it derives from considerably older times. Thus, having obtained this information so promptly after the conquest of Mexico from elders who spoke only Nahuatl, Sahagún made certain that European knowledge or notions had not permeated the information he called. Indeed, since he was not a physician, it is unlikely that Sahagún would have known about the viscosity of the synovial fluid and, even less so, about the possibility of performing an arthrocentesis to relieve it. In fact the first European physician to arrive in Mexico was Dr Francisco Hernández, in $1571 .^{8}$ Not only does the Tetepulco text describe the viscid character of the synovial fiuid, but it also compares it to the fluid which comes out of succulent leaves of the nopal cactus (Fig. 2). The nopal (Opuntia sp. and Opuntia cochinillifera) was indigenous to America, from where it was later transplanted to Europe, North Africa, and Asia owing to the fact that its tender leaves serve as a breeding ground for the cochineal insect, source of a much appreciated red dye. ${ }^{9}$ This cactus has an edible fruit and its most tender leaves are also eaten. When the leaves are cut, much viscid fluid drains from them, and, when they are boiled in salt water for eating, the viscid material floats on the surface of the boiling water and thus can be got rid of. This viscid fluid from the nopal is commonly known as the 'saliva' of the nopal.

Majno $^{10}$ has recently shown that ancient remedies and notions can sometimes be confirmed by presentday experiments. We have determined the viscosity of the juice of the nopal and compared it with that of synovial fluid obtained from patients with various diseases. Nopal leaves were minced and allowed to

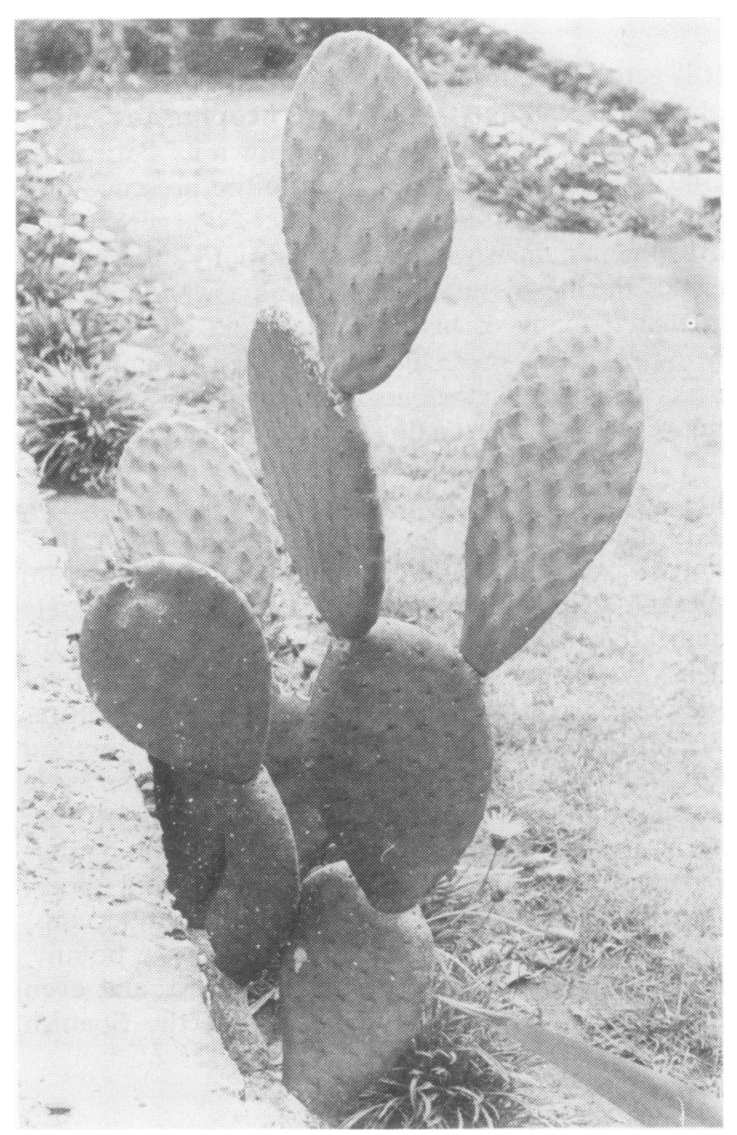

Fig. 2 Nopal cactus (Opuntia sp.) 
drain on a grid. The fluid collected was centrifuged for 30 minutes at $2000 \mathrm{rpm}$ and the supernatant was studied. Viscosity of this and the synovial fluids was determined in an Ostwald viscometer and expressed in relation to that of water. From the findings presented in Table 1 it can be seen that the viscosity of the juice from the nopal was within the range of viscosity of the synovial fluid found in various conditions and actually very close to their mean $(17 \cdot 9)$.

Probably more even important than the description of the viscid nature of the synovial fluid is the description of therapeutic arthrocentesis done to relieve its abnormal formation in the knee. That the collection of fluid was considered abnormal can be inferred from the inclusion of this text among those relating to the Diseases of the Body and by offering a cure for it. The type of thorn used for the arthrocentesis is not specified, but there certainly was no paucity of thorny plants (including the nopal) in the dry sunny climate of the Mexican highlands.

We have previously described how the Indians of prehispanic Mesoamerica had recognised Heberden's nodes ${ }^{11}$ and osteoarthrosis of the knees with the resulting genu varum ${ }^{12}$ and depicted these and many other illnesses in ceramics. ${ }^{13,14}$ Such portrayal of illness was probably not merely accidental but it was probably a part of a cultural complex of prehispanic medicine which included practical and empirical notions with theoretical, religious, and magic concepts. ${ }^{15}, 16$

'History and disease must be, like mind and body, inseparable', ${ }^{17}$ and the history of rheumatic diseases

Table 1 Relative viscosity of the nopal juice as compared to that of synovial fluid

\begin{tabular}{|c|c|c|}
\hline & & $\begin{array}{l}\text { Relative } \\
\text { viscosity* }\end{array}$ \\
\hline $\begin{array}{l}\text { Nopal (opuntia sp.) juice } \\
\text { Synovial fluid }\end{array}$ & & $19 \cdot 5$ \\
\hline Disease & Mucin Clot & \\
\hline Ankylosing spondylitis & I & $46 \cdot 0$ \\
\hline Gout & $\bar{I}$ & $25 \cdot 7$ \\
\hline Traumatic synovitis & II & $14 \cdot 5$ \\
\hline Rheumatoid arthritis & III & 9.6 \\
\hline Behçet's syndrome & III & $7 \cdot 9$ \\
\hline Gout & IV & $3 \cdot 6$ \\
\hline
\end{tabular}

* Mean of 3 measurements. is likewise that of man. The quest for their relief has been universal, as universal as they are. Men who lived in America before the arrival of Columbus both suffered them and took part in this quest.

I thank Ms Eugenia Fishbein for her help in the viscosity studies and Dr Juan Somolinos-Palencia for providing me the portrait of Friar Bernardino de Sahagun.

\section{References}

1 Ropes M W, Bauer W. Synovial Fluid Changes in Joint Disease. Cambridge, Mass: Harvard University Press, 1953.

2 Jessar R A. The study of synovial fluid. In: Hollander J L, McCarthy D J. Arthritis and Allied Conditions, 8th ed. Philadelphia: Lea and Febiger, 1972.

3 Margotta R. The Story of Medicine. New York: Golden Press, 1968.

4 Singer C, Underwood E A. A Short History of Medicine, 2nd ed. Oxford: Clarendon Press, 1962.

5 León-Portilla M. Los Antiguos Mexicanos a Través de sus Crónicas y Cantares, 2nd ed. Mexico City: Fondo de Cultura Económica, 1972.

6 Sahagún B. Historia General de la Cosas de la Nueva España. Mexico City: Editorial Porrua, 1956.

7 López-Austin A. Textos de Medicina Nahuatl. Instituto de Investigaciones Históricas. Universidad Nacional Autónoma de México, Mexico City, 1975.

8 Somolinos D'Ardois G. El Doctor Francisco Hernández y la Primera Expedición Científica en América. Mexico City: Secretaría de Educación Publica, Sepsetentas series, 1971.

9 Baranyovits F L C. Cochineal carmine: an ancient dye with a modern role. Endeavour 2: 85-92.

10 Majno G. The Healing Hand. Man and Wound in the Ancient World. Cambridge, Mass: Harvard University Press, 1975.

11 Alarcón-Segovia D. Pre-columbian representation of Heberden's nodes. Arthritis and Rheum 1976; 19: 125126.

12 Schumacher R H, Alarcón-Segovia D. Osteoarthritic knees in a precolumbian ceramic figure. $J$ Rheumatol 1979 ; in press.

13 Alarcón-Segovia D, de la Fuente J R. Precolumbian representation of disease 1979; submitted for publication.

14 De la Fuente J R. Alarcón-Segovia D. Representation of depression in pre-columbian mexican ceramics. $\mathrm{Am} \mathrm{J}$ Psychiatry 1979; in press.

15 Martinez-Cortés F. Las Ideas en la Medicina Nahuatl. Mexico City: La Pensa Medica Mexicana, 1965.

16 Somolinos D'Ardois G. Historia de la Medicina. Mexico City: Sociedad Mexicana de Historia y Filosofía de la Medicina, 1978.

17 Copeman W S C. A Short History of the Gout and the Rheumatic Diseases. Berkeley: University of California Press, 1964. 